\title{
TECHNIQUES OF MEASURING SPRAY-COOLING HOMOGENEITY
}

\author{
TEHNIKE MERJENJA HOMOGENOSTI HLAJENJA \\ Z BRIZGANJEM
}

\author{
Martin Chabičovský, Miroslav Raudenský \\ Heat Transfer and Fluid Flow Laboratory, Faculty of Mechanical Engineering, Brno University of Technology, Technická 2, 61669 Brno, \\ Czech Republic \\ chabicovsky@LPTaP.fme.vutbr.cz
}

Prejem rokopisa - received: 2013-10-18; sprejem za objavo - accepted for publication: 2014-07-14

doi:10.17222/mit.2013.253

The cooling homogeneity is one of the most important factors that must be considered in the design of cooling sections for the hot rolling of thin sheets. Inhomogeneous cooling can lead to undesirable thermal distortion. The cooling homogeneity is mainly influenced by the water distribution of the cooling section. And so, one way to measure the cooling homogeneity is to measure the impact-pressure distribution of the cooling section. Another way is to measure the surface-temperature distribution of a steel sample during the cooling process. There are two ways to measure the surface temperature and the temperature field: the contact and non-contact measurements. The contact measurement can be performed with thermocouples and the non-contact method is an optical measurement like the one using an infrared scanner. Each of these methods has their advantages and disadvantages. Their comparison was made during an experimental measurement of the cooling of a stainless steel sheet using full-cone water nozzles and a special linear pneumatic sprayer.

Keywords: cooling homogeneity, full-cone nozzles, linear pneumatic sprayer, heat-transfer coefficient

Homogenost ohlajanja je med najpomembnejšimi dejavniki, ki ga je treba upoštevati pri načrtovanju ohlajevalnega področja pri vročem valjanju tankih pločevin. Nehomogeno ohlajanje lahko povzroči neželeno toplotno izkrivljanje. Homogenost ohlajanja je predvsem odvisna od razporeditve vode v območju ohlajanja. Ena od možnosti merjenja homogenosti ohlajanja je merjenje razporeditve tlaka udarca v območju ohlajanja. Druga možnost je merjenje razporeditve temperature na površini vzorca iz jekla med postopkom ohlajanja. Obstajata dva načina za merjenje temperature površine in temperaturnega polja: kontaktno in nekontaktno. Kontaktno merjenje se lahko izvrši s termoelementi, nekontaktno pa z optično meritvijo, kot je na primer infrardeče vrstično tipalo. Vsaka od teh metod ima svoje prednosti in slabosti. Izvršena je bila eksperimentalna primerjava merjenja ohlajanja pločevine iz nerjavnega jekla $v$ območju vodnih šob in s posebnim linearnim pnevmatskim brizgalnikom.

Ključne besede: homogenost ohlajanja, območje s šobami, linearni pnevmatski brizgalnik, koeficient prehoda toplote

\section{INTRODUCTION}

The intensive cooling of thin sheets during hot rolling or heat treatment is mainly conducted with water. Cooling with water provides high cooling rates compared to gas cooling, but these can be associated with undesirable problems of the homogeneity of cooling. Inhomogeneous cooling can lead to non-homogeneous material properties and also to thermal distortion. The cooling homogeneity is one of the most important factors that must be considered in the design of water-cooling sections for the hot rolling or the heat treatment of thin sheets.

Cooling hot surfaces with water is associated with different regimes of boiling. The film-boiling regime occurs when the surface temperature is higher than the Leidenfrost temperature ${ }^{1}$ (Figure 1). The surface is covered with a vapor layer which protects the surface and lowers the cooling intensity during the film-boiling regime. When the surface temperature drops below the Leidenfrost temperature, the vapor layer is broken and the transient and nucleate boiling regime occurs, which is characterized by high cooling intensities. A large inho- mogeneity of the surface-temperature distribution can mostly be observed when the temperature of one part of the cooled surface is below the Leidenfrost temperature and another is above the Leidenfrost temperature. This is well demonstrated in Figure 1. The temperature record at time $T 1$ corresponds to the heat-transfer coefficient HTC T1. This heat-transfer coefficient has a Leidenfrost

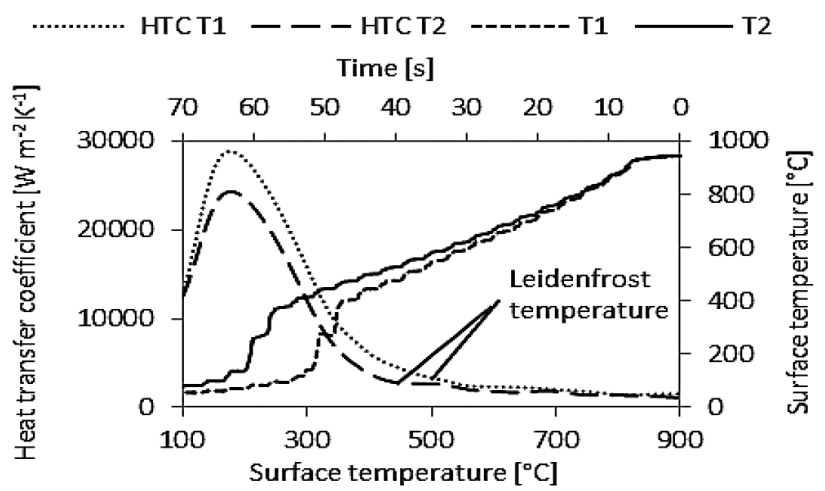

Figure 1: Simulation of the cooling process

Slika 1: Simulacija postopka ohlajanja 


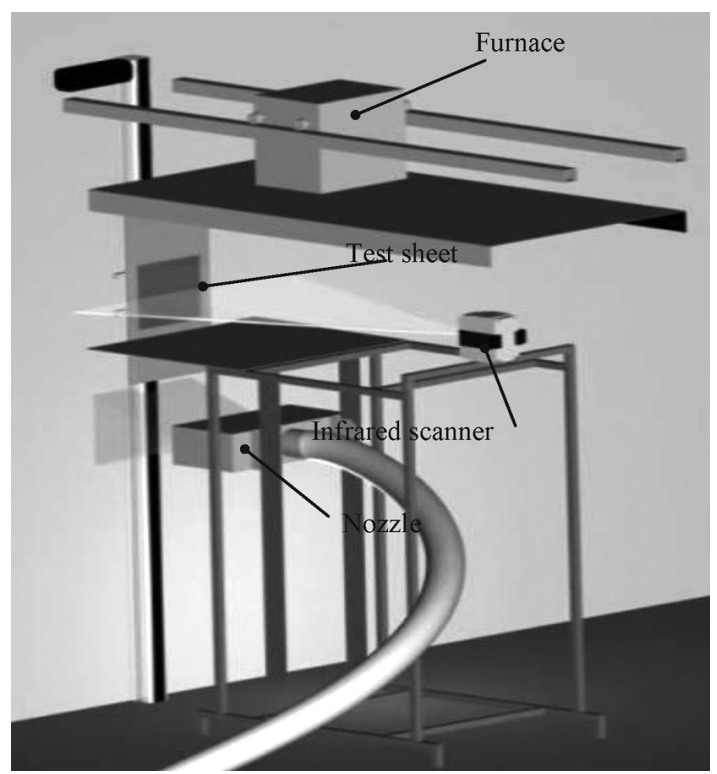

Figure 2: Experimental apparatus for measuring cooling homogeneity with thermocouples and an infrared scanner

Slika 2: Eksperimentalna naprava za merjenje homogenosti ohlajanja $\mathrm{s}$ termoelementi in infrardečim vrstičnim tipalom

temperature of approximately $500{ }^{\circ} \mathrm{C}$. And so the intensive cooling caused by the breaking up of the vapor layer starts at a time of $44 \mathrm{~s}$. The distribution of the heat-transfer coefficient HTC $T 2$ has a Leidenfrost temperature of $450{ }^{\circ} \mathrm{C}$. This temperature relates to the start of a rapid decrease in temperature $T 2$ at a time of 50 $\mathrm{s}$. This is why the difference in the temperature is almost $300{ }^{\circ} \mathrm{C}$ between $50 \mathrm{~s}$ and $60 \mathrm{~s}$ although the difference between the heat-transfer coefficients is small, especially for the surface temperatures higher than $500{ }^{\circ} \mathrm{C}$.

The best way of measuring the cooling inhomogeneity during the cooling of thin sheets is to do it in the plant. However, because this method is very expensive, laboratory experimental methods simulating the plant conditions should be taken into account. With the reported technique we simulated a cooling process involving a small sheet, and measured the distribution of surface temperatures during the cooling process either with the contact method using thermocouples or the non-contact method using an infrared scanner. As the cooling intensity is mainly influenced by the water distribution and impact velocity ${ }^{2,3}$ the cooling homogeneity can be evaluated by measuring the impact-pressure distribution of the cooling section. The experimental methods for the measurement of the cooling inhomogeneity are described below.

\section{EXPERIMENT}

\subsection{Measurement of spray-cooling homogeneity}

An experimental study was performed to compare three different methods of measuring the cooling homogeneity. The homogeneity of cooling was measured during the cooling process with thermocouples and an infrared scanner. The cooling homogeneity was also investigated during cold tests when the impact pressure was measured.

The experiments for this comparison were conducted with three different nozzle configurations, which provided three different levels of cooling homogeneity.

The configuration with a very good cooling homogeneity (Configuration 1) was composed of a row of fullcone nozzles. The distance between the full-cone nozzles was $80 \mathrm{~mm}$ and the distance from the nozzle orifices to the test sheet was $250 \mathrm{~mm}$. The water pressure was 130 $\mathrm{kPa}$. The spray angle was $60^{\circ}$ and the water impingement density in the impact area was $12.07 \mathrm{~kg} \mathrm{~m}^{-2} \mathrm{~s}^{-1}$. Configuration 2 was a configuration with a medium cooling homogeneity and Configuration 3 provided very inhomogeneous cooling. Configurations 2 and 3 were composed of a special linear pneumatic spray box which is well described in ${ }^{4}$.

The distance between the nozzle orifice and the test sheet was $250 \mathrm{~mm}$ and the spray angle was $60^{\circ}$. The water pressure was $130 \mathrm{kPa}$ for Configuration 2 and 600 $\mathrm{kPa}$ for Configuration 3. The air pressure was $8.5 \mathrm{kPa}$ for Configuration 2 and $10.5 \mathrm{kPa}$ for Configuration 3 .

The water impingement density was $9.76 \mathrm{~kg} \mathrm{~m}^{-2} \mathrm{~s}^{-1}$ for Configuration 2 and $20.64 \mathrm{~kg} \mathrm{~m}^{-2} \mathrm{~s}^{-1}$ for Configuration 3.

One way to measure the temperature is using the thermocouples welded onto the rear side of the test sheet which, with the help of inverse methods, determines the surface temperatures. The other method uses an infrared scanner for a direct measurement of the surface temperatures during the cooling process. The apparatus for measuring the temperatures using an infrared scanner and thermocouples is shown in Figure 2. Details of the experimental apparatus and the experimental set-up are described in ${ }^{5,6}$. Hot tests were conducted with the austenitic stainless-steel sheets with a thickness of $2 \mathrm{~mm}$, a height of $300 \mathrm{~mm}$ and a width of $320 \mathrm{~mm}$. A test sheet was heated in a furnace with a protective atmosphere at a temperature of $950{ }^{\circ} \mathrm{C}$. After the heating, the test sheet moved down with a velocity of $3 \mathrm{~m} \mathrm{~s}^{-1}$ and passed through the cooling section. Then it moved up through the cooling section and stopped for $1.5 \mathrm{~s}$ above the cooling section. During this time the infrared scanner measured the surface temperature. Then the test sheet moved down and repeated the previous steps until it was cooled to a temperature of $200{ }^{\circ} \mathrm{C}$. During the experiment, the temperature of the sheet was measured with five type-K thermocouples with a frequency of $320 \mathrm{~Hz}$. The thermocouples were welded onto the rear side of the test sheet. One thermocouple was welded in the center of the test sheet and the distance between the thermocouples was $20 \mathrm{~mm}$ (for more details see reference ${ }^{5}$ ). The distance between the infrared scanner and test sheet was $1500 \mathrm{~mm}$. The frequency of the measurement was $36 \mathrm{~Hz}$ and the resolution was 1024 points per line. 


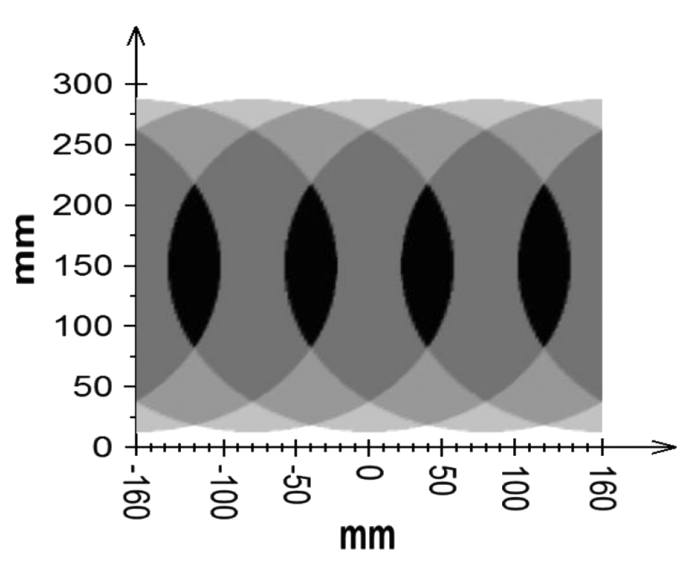

Figure 3: Water distribution for Configuration 1 Slika 3: Razporeditev vode pri postavitvi 1

Impact-pressure tests were conducted with a pressure sensor with a diameter of $12 \mathrm{~mm}$ and during the test the impact pressure was measured on the whole area that was influenced by the spraying nozzles, with a step of 10 $\mathrm{mm}$ in the direction of the $X$-axis and $20 \mathrm{~mm}$ in the direction of the $Y$-axis.

\section{RESULTS AND DISCUSSION}

\subsection{Thermocouples}

The use of thermocouples for measuring the cooling homogeneity has some restrictions. Thermocouples can be placed only in a finite number of positions. So, it is necessary to know the positions, in which inhomogeneity can be expected. The water distribution can serve as the first source of information about the expected cooling homogeneity. An example of the computed water distribution is shown in Figure 3. The information about the water distribution is necessary when deciding where to place the thermocouples. The thermocouples were installed in positions of $0 \mathrm{~mm}$ and $40 \mathrm{~mm}$ (Figure 3) for Configuration 1 . The position of $40 \mathrm{~mm}$ corresponds to the position with the highest water impingement density and the position of $0 \mathrm{~mm}$ is the position with the lowest water impingement density. The measured temperatures are shown in Figure 4. The temperatures are almost the same for the positions of $0 \mathrm{~mm}$ and $40 \mathrm{~mm}$. The surface

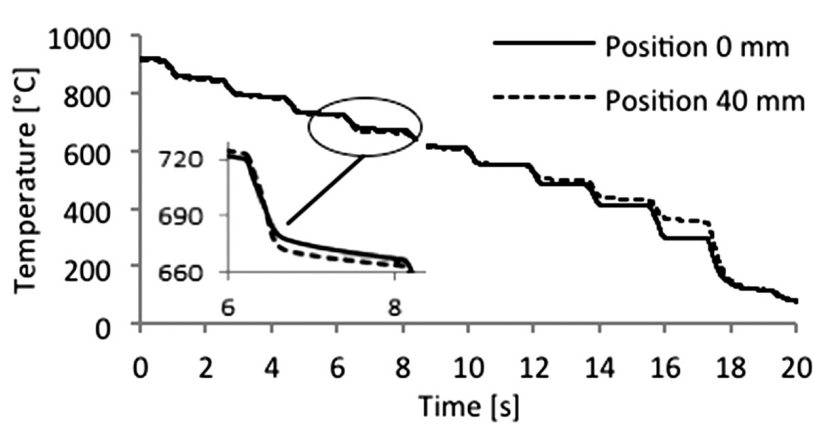

Figure 4: Measured temperatures for Configuration 1 Slika 4: Izmerjene temperature pri postavitvi 1

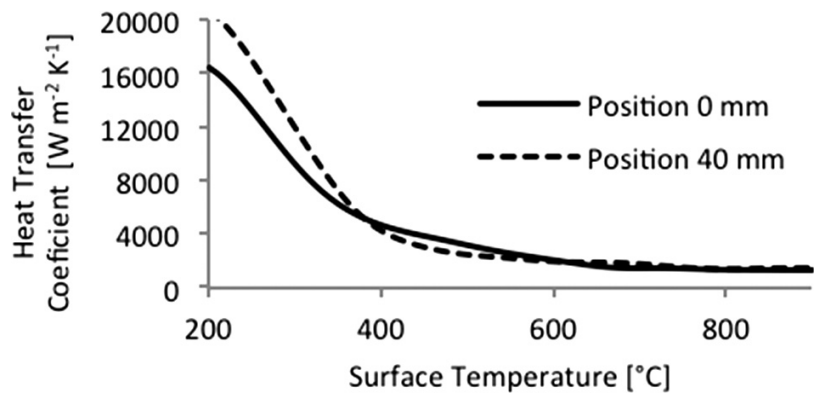

Figure 5: Heat-transfer coefficient for Configuration 1 Slika 5: Koeficient prehoda toplote pri postavitvi 1

temperatures and the heat-transfer coefficients can be computed at these positions using inverse methods. ${ }^{7-9}$ The computed dependence of the heat-transfer coefficient on the surface temperature is shown in Figure 5. The dependence of the heat-transfer coefficient on the surface temperature also shows a very good homogeneity of the cooling, obviously for the surface temperatures higher than $600{ }^{\circ} \mathrm{C}$.

\subsection{Infrared scanner}

Although the measurement with an infrared scanner provides information about the surface temperature of the overall surface area, and these measured temperatures can be directly used for the evaluation of the cooling homogeneity, this method of measuring the cooling homogeneity needs a more complicated experimental set-up. The precision of the non-contact measurement is not as good as in the case of thermocouples. There are several factors that have a considerable influence on the quality of measurement. One of them is emissivity. Information about emissivity is necessary for obtaining surface temperatures. Emissivity depends on the properties of the surface (material, temperature, presence of oxides and others) and the surface properties change during the cooling process. If a sheet is heated in a protective atmosphere and removed from the furnace, its surface is like a mirror and the emissivity is lower than during the cooling process due to different surface temperatures and the presence of scales on the surface. The scales on the surface enhance the emissivity. Uneven

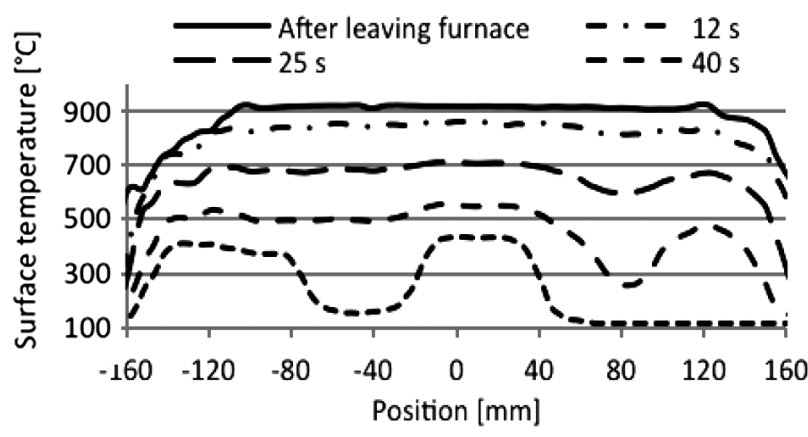

Figure 6: Surface temperatures at given times for Configuration 2 Slika 6: Temperature površine pri danih časih pri postavitvi 2 


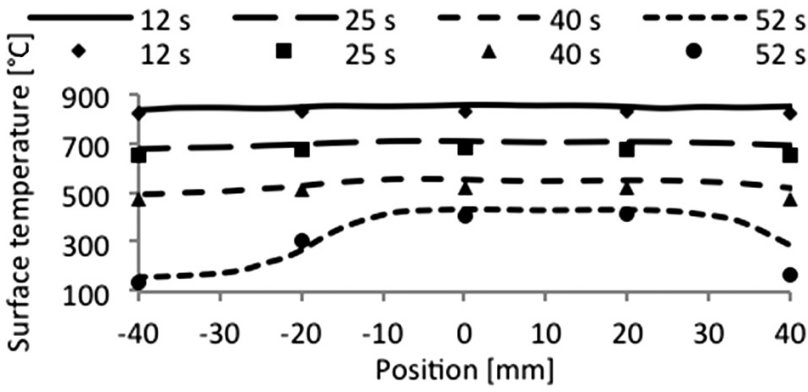

Figure 7: Comparison of the surface temperatures measured with the infrared scanner (lines) and with the thermocouples (marks: $\bullet, \mathbf{\square}, \boldsymbol{\Delta}$ and $\bullet$ )

Slika 7: Primerjava temperature na površini, izmerjene z infrardečim vrstičnim tipalom (polna črta) in izmerjene s termoelementi (oznake: $\bullet, \mathbf{v}, \boldsymbol{\Delta}$ in $\bullet$ )

scale coverage of the surface is a problem and can lead to errors in the measurement of the surface temperatures and an incorrect conclusion regarding the cooling homogeneity.

The temperature that is measured can also be influenced by the presence of water droplets and vapor in the air between the sheet and the infrared scanner. The water remaining on the sheet and the radiation from the surroundings also prevent the measured temperatures from reflecting the reality. The presence of vapor and water droplets in the air or a water layer on the surface can smooth a low temperature inhomogeneity or cause the measured temperatures to be lower or higher than the real temperatures. The radiation from the surroundings can cause the temperatures measured in some positions to be higher than in reality. All the above factors should be considered during the measurement preparation to obtain realistic results. An example of the temperatures measured with the infrared scanner is shown in Figure 6. The position of $0 \mathrm{~mm}$ was in the center of the test sheet with a width of $320 \mathrm{~mm}$ and the temperatures were measured in the centerline of the test sheet. The temperature was also measured with five thermocouples during the cooling process and the comparison is shown in Figure 7. The thermocouples were welded on at the positions of $(-40,-20,0,20$ and 40$) \mathrm{mm}$. The surface temperatures that were measured with the thermocouples and computed with an inverse task were slightly lower

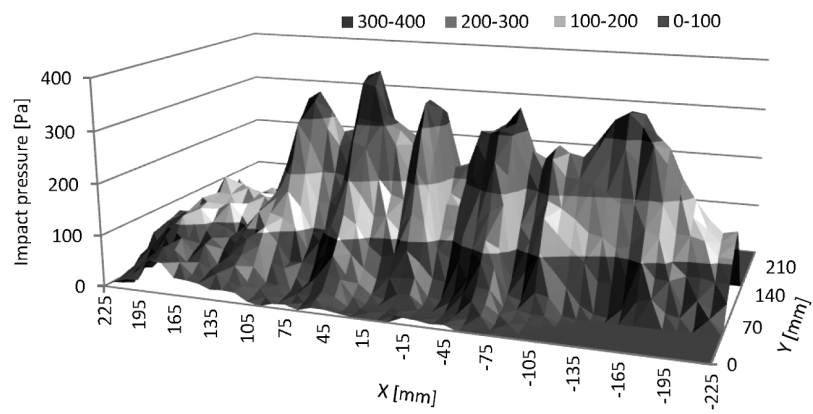

Figure 8: Impact-pressure distribution for Configuration 2 Slika 8: Razporeditev dinamičnega tlaka pri postavitvi 2

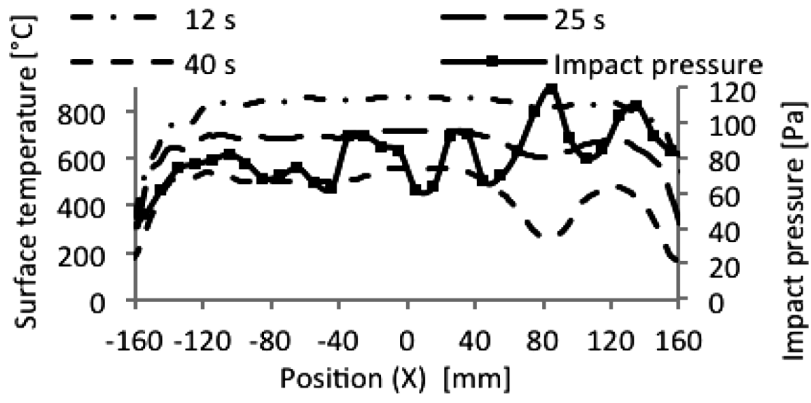

Figure 9: Comparison of the impact pressure with the measured surface temperatures for Configuration 2

Slika 9: Primerjava dinamičnega tlaka pri izmerjeni temperaturi površine pri postavitvi 2

than the temperatures measured with the infrared scanner. There is only one big difference between the temperatures measured with the infrared scanner and those measured with the thermocouples. It is found in the position of $40 \mathrm{~mm}$ at a time of $52 \mathrm{~s}$. The difference is approximately $120{ }^{\circ} \mathrm{C}$. It can be explained with the water layer on the surface in this position. The homogeneity of cooling is almost the same with both methods.

\subsection{Impact pressure}

The measurement of the impact pressure is an indirect method for measuring the cooling homogeneity because the real surface temperature is not measured during the cooling process. An example of the measured impact-pressure distribution is shown in Figure 8. Its average value over the width of the spray configuration ( $Y$-axis) of Configuration 2 is compared with the surface temperatures measured for this configuration with the infrared scanner in Figure 9.

Although the impact-pressure distribution looks inhomogeneous, the surface temperatures at the times of $12 \mathrm{~s}$ and $25 \mathrm{~s}$ look homogeneous except at the position of $80 \mathrm{~mm}$. This is why the surface temperatures are higher than the Leidenfrost temperature and the vapor layer protects the surface and only a significant inhomogeneity of the impact pressure is observed during the real cooling. This was confirmed during the experiment with Configuration 3 (Figure 10). The surface temperatures

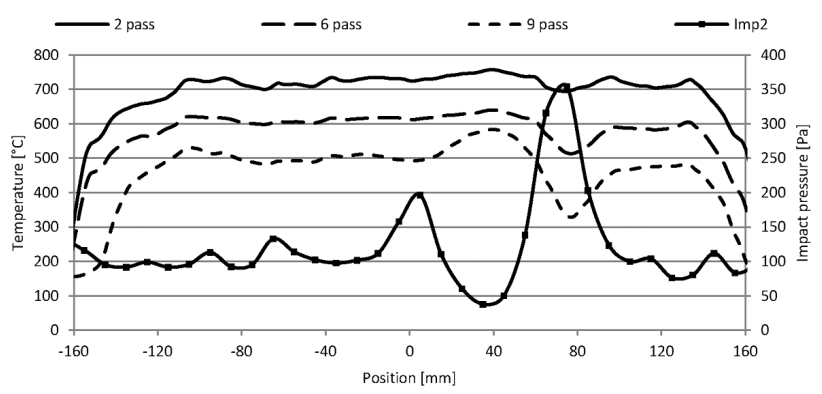

Figure 10: Comparison of the impact pressure with the surface-temperature distribution for Configuration 3

Slika 10: Primerjava dinamičnega tlaka $\mathrm{z}$ razporeditvijo temperature pri postavitvi 3 
after the second pass through the cooling section (pass 2) fit well with the impact-pressure distribution (Imp. 2) only at the position of $80 \mathrm{~mm}$. When the surface temperature is lower than the Leidenfrost temperature (pass 9) almost every increase or decrease in the impact pressure is reflected in the surface-temperature distribution.

\section{CONCLUSIONS}

The thermocouples provided accurate and reliable information about the cooling homogeneity, though only in a finite number of positions. The benefit of the infrared scanner was that the cooling homogeneity was measured on all the surface area; but to obtain accurate values of the measurement, a demanding measurement preparation was necessary. The homogeneity of the impact-pressure distribution corresponded with the homogeneity of the measured surface temperatures only for the surface temperatures below the Leidenfrost temperature. During the test with a hot test plate, a large inhomogeneity of the impact pressure was observed only for the surface temperatures higher than the Leidenfrost temperature.

\section{Acknowledgement}

This work is an output of research and scientific activities of this project LO1202 with financial support of the MEYS under the programme NPU I and the internal grant of the Brno University of Technology focused on specific research and development No. FSI-S-14-2437.

\section{REFERENCES}

${ }^{1}$ S. Nukiyama, The Maximum and Minimum Values of the Heat Q Transmitted from Metal to Boiling Water Under Atmospheric Pressure, International Journal of Heat and Mass Transfer, 9 (1966) 12, 1419-1433, doi:10.1016/0017-9310(66)90138-4

${ }^{2}$ J. Wendelstorf, K. H. Spitzer, R. Wendelstorf, Spray water cooling heat transfer at high temperatures and liquid mass fluxes, International Journal of Heat and Mass Transfer, 51 (2008) 19-20, 4902-4910, doi:10.1016/j.ijheatmasstransfer.2008.01.032

${ }^{3}$ S. C. Yao, T. L. Cox, A general heat transfer correlation for impacting water sprays on high-temperature surfaces, Experimental Heat Transfer, 15 (2002) 4, 207-219, doi:10.1080/08916150290082649

${ }^{4}$ J. Rivallin, S. Viannay, General principles of controlled water cooling for metallurgical on-line hot rolling processes: forced flow and sprayed surfaces with film boiling regime and rewetting phenomena, International Journal of Thermal Sciences, 40 (2001) 3, 263-272, doi:10.1016/S1290-0729(00)01216-3

${ }^{5}$ M. Chabicovsky, M. Raudensky, Experimental Investigation of a Heat Transfer Coefficient, Mater. Tehnol., 47 (2013) 3, 395-398

${ }^{6}$ M. Chabičovský, M. Raudenský, Experimental investigation of spray cooling of horizontally and vertically oriented surfaces, Proc. of the 22nd International Conference on Metallurgy and Materials METAL 2013, Brno, 2013, 198-202

${ }^{7}$ M. Raudensky, Heat Transfer Coefficient Estimation by Inverse Conduction Algorithm, International Journal of Numerical Methods for Heat and Fluid Flow, 3 (1993) 3, 257-266, doi:10.1108/eb017530

${ }^{8}$ M. Pohanka, K. A. Woodbury, A Downhill Simplex method for computation of interfacial heat transfer coefficients in alloy casting, Inverse Problems in Engineering, 11 (2003) 5, 409-424, doi:10.1080/1068276031000109899

${ }^{9}$ M. Pohanka, P. Kotrbáček, Design of Cooling Units for Heat Treatment, In: F. Czerwinski (ed.), Heat Treatment - Conventional and Novel Applications, chapter 1, InTech, 2012, 1-20, doi:10.5772/ 50492 